\title{
Review \\ Ethanol Biofuel Cells: Hybrid Catalytic Cascades as a Tool for Biosensor Devices
}

\author{
Jefferson Honorio Franco $^{1}\left(\mathbb{D}\right.$, , Shelley D. Minteer ${ }^{2, *(\mathbb{D})}$ and Adalgisa R. De Andrade ${ }^{1, *(\mathbb{D})}$ \\ 1 Department of Chemistry, Faculty of Philosophy Sciences and Letters at Ribeirão Preto, \\ University of São Paulo, Ribeirão Preto, Sao Paulo 14040-901, Brazil; jeffersonhfranco@gmail.com \\ 2 Department of Chemistry, University of Utah 315 S 1400 E Rm 2020, Salt Lake City, UT 84112, USA \\ * Correspondence: minteer@chem.utah.edu (S.D.M.); ardandra@usp.br (A.R.D.A.)
}

check for updates

Citation: Franco, J.H.; Minteer, S.D.; De Andrade, A.R. Ethanol Biofuel Cells: Hybrid Catalytic Cascades as a Tool for Biosensor Devices. Biosensors 2021, 11, 41. https://doi.org/ 10.3390/bios11020041

Received: 12 January 2021

Accepted: 1 February 2021

Published: 4 February 2021

Publisher's Note: MDPI stays neutral with regard to jurisdictional claims in published maps and institutional affiliations.

Copyright: (c) 2021 by the authors. Licensee MDPI, Basel, Switzerland. This article is an open access article distributed under the terms and conditions of the Creative Commons Attribution (CC BY) license (https:/ / creativecommons.org/licenses/by/ $4.0 /)$.

\begin{abstract}
Biofuel cells use chemical reactions and biological catalysts (enzymes or microorganisms) to produce electrical energy, providing clean and renewable energy. Enzymatic biofuel cells (EBFCs) have promising characteristics and potential applications as an alternative energy source for low-power electronic devices. Over the last decade, researchers have focused on enhancing the electrocatalytic activity of biosystems and on increasing energy generation and electronic conductivity. Self-powered biosensors can use EBFCs while eliminating the need for an external power source. This review details improvements in EBFC and catalyst arrangements that will help to achieve complete substrate oxidation and to increase the number of collected electrons. It also describes how analytical techniques can be employed to follow the intermediates between the enzymes within the enzymatic cascade. We aim to demonstrate how a high-performance self-powered sensor design based on EBFCs developed for ethanol detection can be adapted and implemented in power devices for biosensing applications.
\end{abstract}

Keywords: biofuel cell; hybrid system; biosensor

\section{Enzymatic Biofuel Cells (EBFCs)}

In 1911, Potter et al. demonstrated the first biofuel cell (BFC), which contained yeast cells at the anode and oxidized glucose [1]. Decades later, in the 1960s, Kimble and collaborators showed the initial proof-of-concept of "enzymatic biofuel cells" (EBFCs) by fixing glucose oxidase (GOx) on the surface of an electrode. The fact that an enzyme was able to produce electricity was essential to raising interest in the field of bioelectrochemistry [2].

BFCs resemble conventional fuel cells. The main difference is that metallic catalysts are replaced with enzymes and/or microorganisms in EBFCs and microbial fuel cells, respectively [3]. In BFCs, the biocatalyst at the anode promotes oxidation of the target fuel. The preferred reaction at the cathode is oxygen reduction, which can also be catalyzed by enzymes, such as laccase (Lac) or bilirubin oxidase (BOX) [4,5], or by microorganisms [6]. To produce electricity, electrons released at the anode reach the cathode via an external circuit, as illustrated in Figure 1. The useful energy generated in the system depends on the difference between the anode and the cathode potentials [7].

Advances in the use of isolated enzymes as biocatalysts have been made thanks to (i) the various reactions that enzymes can catalyze with unequaled specificity even in the presence of impurities [8], (ii) the greater potential of isolated enzymes for in vivo applications [9], (iii) the higher power density values provided by EBFCs as compared to microbial fuel cells (where the microorganism cell membrane limits mass and electron transfer) [10], and (iv) the possibility of operating EBFCs at neutral $\mathrm{pH}$. However, the experimental power and energy density of these systems are lower than the theoretical 
performance $[3,11,12]$. Thus, to optimize self-energy generation, the factors that contribute to decreased cell potential must be optimized [7]:

$$
\mathrm{E}_{\text {cell }}=\left(\Delta_{\mathrm{Ec}-\mathrm{Ea}}\right)-\Delta \eta-\Sigma \Omega
$$

where Ec and Ea are the thermodynamic potentials for the cathode and the anode, respectively; $\Delta \eta$ is the overvoltage of the anodic and cathodic reactions $(\Delta \eta$ takes the slow kinetics and the mass transfer rate into account); and $\Sigma \Omega$ is the sum of the internal resistances of the cell [7]. Energy harvesting and the power output of EBFCs must be optimized so that this technology can become as useful as commercial batteries and conventional fuel cells. Therefore, current efforts in the field of BFCs have been focused on developing new methodologies and materials integrated with enzymes to increase the useful life, power density output, and consumption of all the energy potentials of the biofuel until it is completely oxidized to $\mathrm{CO}_{2}[13,14]$.

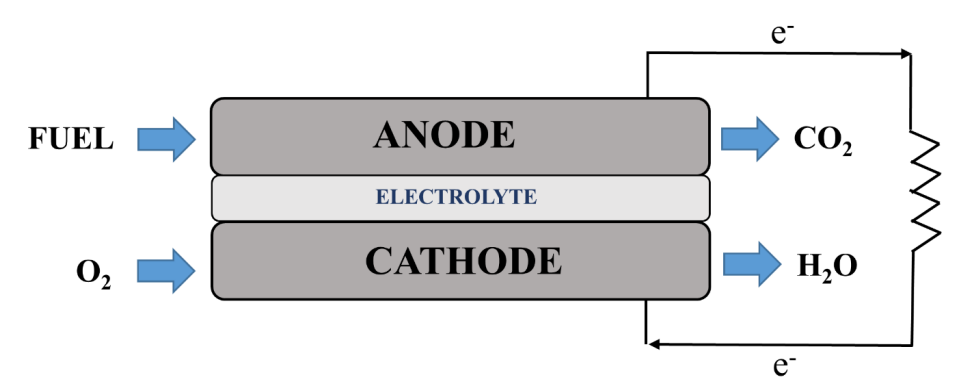

Figure 1. Representative scheme of a biofuel cell operation: the fuel is oxidized at the anode, and oxygen is reduced at the cathode so that chemical energy is converted to electrical energy.

\section{Enzymatic Cascades}

In recent years, research into EBFCs has focused on understanding how enzymes function on electrode surfaces and on developing methods for the application of enzymes on these surfaces. To enhance the power density of EBFCs, the degree of fuel oxidation must be increased so that all electrons can be harvested from complex fuels [15]. EBFCs generally employ enzymes to collect energy from biofuels $[3,11,16]$. These enzymes catalyze the oxidation of various fuels at room temperature and in mild aqueous environments, offering high theoretical efficiency while producing nontoxic reaction residues $[12,15,17,18]$.

To increase the degree of fuel oxidation, multiple enzymes have been immobilized on electrode surfaces [19]. These systems can oxidize more complex fuels, thereby enhancing power density and energy generation $[12,20,21]$. Nevertheless, mechanically and chemically stable layers that employ a large number of enzymes almost always afford poorly stable bioelectrodes [12]. Different specific operating conditions $(\mathrm{pH}$, temperature, substrate specificity, and electrolytes) of the enzymes in the enzymatic cascade limit film stability. Our group has shown that, compared to a bi-enzymatic anode, a multi-enzymatic system involving six enzymes did not furnish higher power density for ethanol bioelectrooxidation [22] because immobilization of the six enzymes on the same matrix limited their functions and culminated in lower bioelectrocatalytic rate [22].

Therefore, for the theoretical energy (all the electrons) of a fuel to be completely harvested, new methodologies that rely on new materials (e.g., nanostructures, hybrid catalysts, and modified catalysts) integrated with enzymes must be developed [23].

\section{New Trends in EBFCs: Hybrid Cascades for Ethanol Electrooxidation Pathways}

Many research groups, including ours, have been investigating EBFCs [21,24-27]. Using ethanol as fuel is attractive because it is low in toxicity, has a high energy density $\left(8.6 \mathrm{kWh} \mathrm{kg}^{-1}\right)$, and is produced worldwide [24,26-28]. This renewable fuel has promising characteristics for the development of energy conversion devices, especially for application in biosensors [10,29-31]. However, ethanol oxidation through a multi-enzymatic cascade 
is complicated: a large number of enzymes are required for this fuel to be completely oxidized [12,22]. In an attempt to obtain improved results during the development of BFCs, we have recently investigated electrochemical ethanol oxidation to $\mathrm{CO}_{2}$ by using a hybrid biocatalyst consisting of less specific organic catalysts and enzymes integrated into nanostructured materials [32-34]. The results regarding the collection of the maximum number of electrons from different alcohols such as glycerol $[35,36]$ and ethanol $[32,33]$ were interesting. 2,2,6,6-Tetramethylpiperidine-N-oxyl (TEMPO), which oxidizes alcohols and aldehydes, was employed as an organic catalyst [29,30]. Electrochemical oxidation with TEMPO generates a hydroxylamine, which produces the nitroxyl radical and completes the catalytic cycle $[37,38]$. Nevertheless, TEMPO does not remove all the electrons from the substrate because it cannot cleave carbon-carbon bonds. In this situation, complete alcohol oxidation could be boosted by employing hybrid systems that combine TEMPO with enzymes that can specifically cleave C-C bonds [32,36-38]. In fact, nanostructured materials are being increasingly studied to enhance the power density output of EBFCs. The modern design of catalysts for BFCs must incorporate nanoscale materials (carbon nanotubes, nanofibers, graphene, and nanocomposites) into the bioelectrode structure [39]. Research into nanostructured materials has demonstrated excellent entrapment of the immobilized macromolecule: these materials provide a more adequate environment for enzymatic anchoring, allowing for higher enzyme loading and thus increasing the kinetic process efficiency. The presence of these nanomaterials improves the electrical contact between the active sites of the enzymes and the electrode surface, enhancing the bioelectrode electroactivity [40].

Within the field of BFCs, multi-walled carbon nanotubes (MWCNTs) are attractive due to their outstanding features: they display (i) large specific surface area, (ii) high mechanical strength, (iii) high conductivity, (iv) good biocompatibility, and (v) antifouling properties [41]. Moreover, MWCNTs can be electrically connected with many redox enzymes [42] or can be modified with functional groups for further immobilization of biomolecules $[43,44]$.

Given that the combination of nanoparticles with biomaterials provides systems with improved electronic and catalytic properties, hybrid nanobiomaterials have been developed to achieve higher catalytic power and power densities [45].

\section{Complete Ethanol Oxidation by Systems Based on Hybrid Enzymatic Electrodes and Organic Catalysts}

We were the first to report on a hybrid system containing TEMPO and enzymes for use in an EBFC [32]. This bi-catalytic system combined carboxylated multi-walled carbon nanotubes (MWCNT-COOH), TEMPO-modified linear poly(ethylenimine), and alcohol (ADH) and aldehyde (AldDH) dehydrogenase immobilized on an linear poly(ethylenimine) (LPEI) backbone crosslinked carbon electrode. This system cleaved the acetic acid C-C bond to give $\mathrm{CO}_{2}$ as the final product (12 electrons). In other words, this immobilized hybrid bi-catalytic system yielded high electrochemical oxidation rates and complete ethanol oxidation to $\mathrm{CO}_{2}$. The long-term $(12 \mathrm{~h})$ electrolysis chromatographic data revealed high $\mathrm{CO}_{2}$ yields and confirmed total ethanol oxidation to $\mathrm{CO}_{2}$. The hybrid biofilm consisting of MWCNT/TEMPO-LPEI/ADH + AldDH improved the immobilization system and may be employed to build hybrid architectures for biosensors [32].

Seeking to improve catalytic systems further, our group later reported complete ethanol oxidation in hybrid systems containing the organic catalyst TEMPO and enzymes that can cleave the $\mathrm{C}-\mathrm{C}$ bond, such as oxalate oxidase (OxOx) [33] and oxalate decarboxylase $(\mathrm{OxDc})[34,46]$. It was the first time that a hybrid system containing an organic catalyst and an oxidase/decarboxylase enzyme was reported to oxidize ethanol more efficiently than previously reported hybrid systems [34,46].

The hybrid system containing pyrene-TEMPO immobilized on the surface of MWCNT$\mathrm{COOH}$ and $\mathrm{OxDc}$ deposited on a carbon cloth electrode deserves highlighting. This new bicatalytic architecture provided EBFCs with a longer useful lifetime and higher power density values and electrocatalytic performance $[33,34,46]$. Despite the challenges in cleaving 
the $\mathrm{C}-\mathrm{C}$ bond of the acetate intermediate, this new hybrid bifunctional enzymatic/organic electrocatalyst electron-harvesting design allowed 12 electrons to be collected per ethanol molecule and produced more energy through complete ethanol oxidation, as shown in Figure 2 .

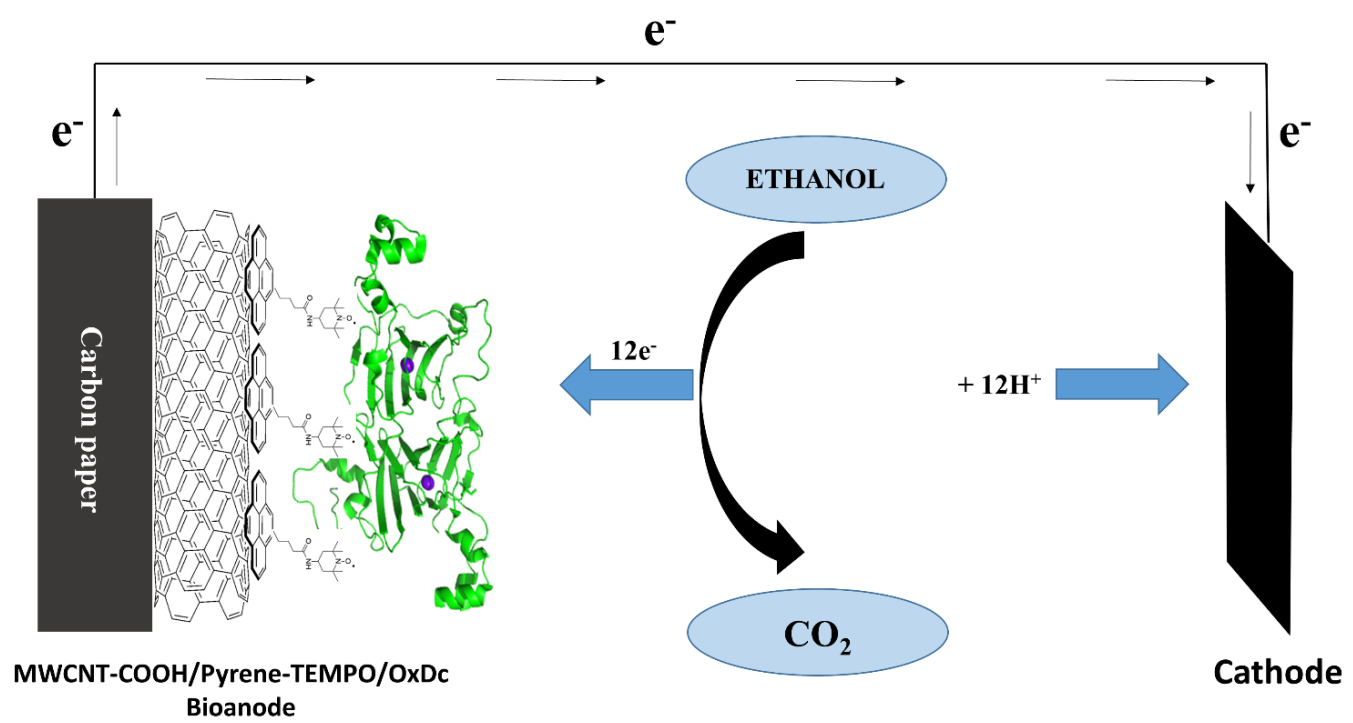

Figure 2. Scheme of complete ethanol oxidation at a hybrid bi-catalytic anode (carboxylated multi-walled carbon nanotube (MWCNT-COOH)/pyrene-2,2,6,6-tetramethylpiperidine-N-oxyl (TEMPO)/oxalate decarboxylase (OxDc)).

Scheme 1 depicts the proposed electrocatalytic cascade for ethanol oxidation when a hybrid bi-catalytic architecture is used [34]. The enzymatic pathway acts on the product formed by the TEMPO catalyst. The combination of pyrene-TEMPO and OxDc allows for high-energy production. Furthermore, the introduction of MWCNT-COOH improves the electron transfer rate between the enzymes and the electrode surface.

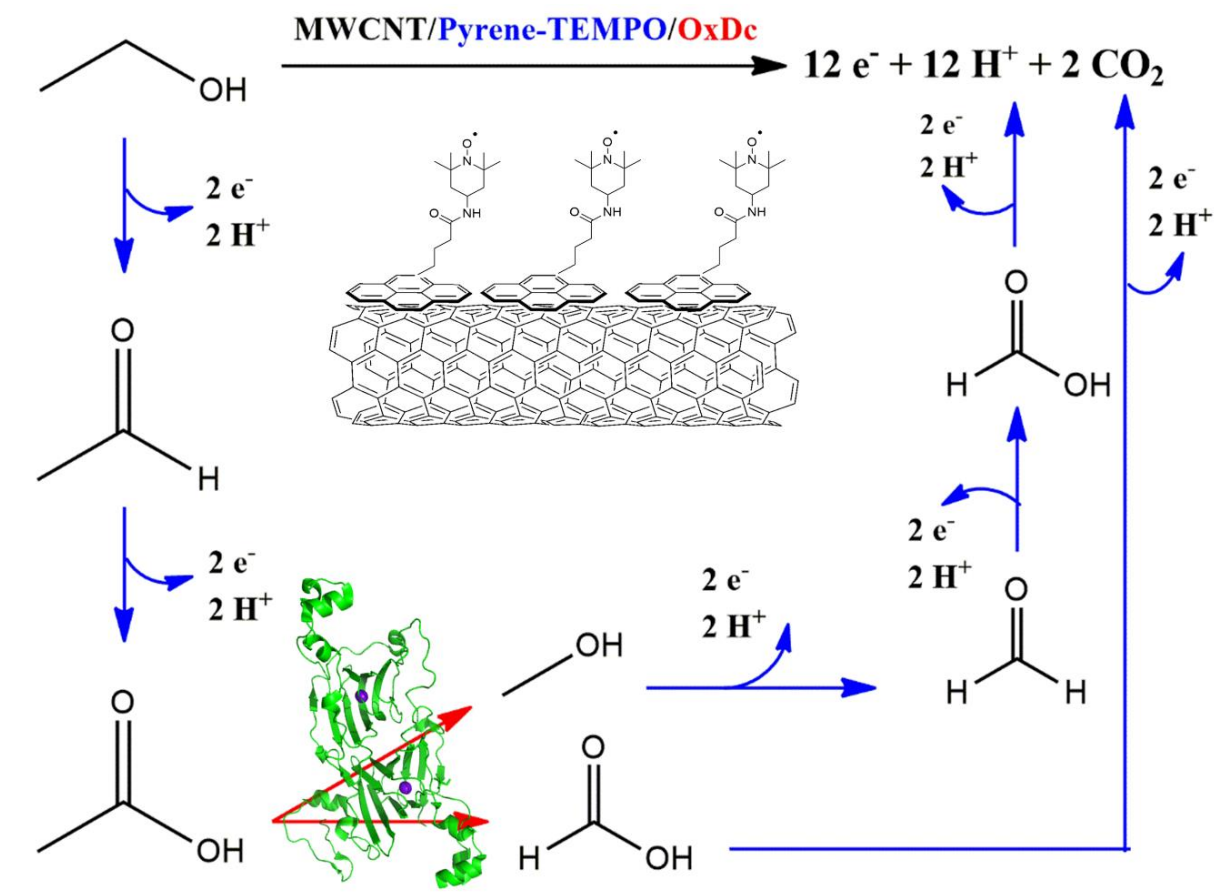

Scheme 1. Hybrid cascade for ethanol oxidation at the MWCNT-COOH/pyrene-TEMPO/OxDc electrode: oxidation mediated by pyrene-TEMPO (blue arrows) and oxidation mediated by the OxDc enzyme (red arrows). Reprinted with permission from [34]. Copyright 2020. 


\section{Analytical Techniques Employed with Ethanol EBFCs}

Analytical techniques are critical tools for identifying and quantifying electrolysis products and for confirming important parameters such as mass transfer efficiency and kinetic rates at the electrode and in electron harvesting from the fuel. Although several groups have reported complete alcohol oxidation on the basis of electrochemical results $[12,19,47]$, a reliable and sensitive technique is necessary to determine and quantify the products generated during fuel oxidation in BFCs. In the area of bioelectrochemistry, identifying such products is crucial because it paves the way for improving the construction of efficient devices.

Analytical techniques provide insight into how BFCs operate. We used high- performance liquid chromatography (HPLC) coupled with a refractive index detector (RID) to investigate ethanol BFC [21]. To achieve the best results for ethanol oxidation, we employed an Aminex HPX-87H (Bio-Rad) column in the isocratic mode and sulfuric acid $\left(5 \mathrm{mmol} \mathrm{L}^{-1}\right.$ ) at a flow rate of $0.6 \mathrm{~mL} \mathrm{~min}^{-1}$ as the mobile phase. We selected the Aminex HPX-87H column because it can identify and detect volatile fatty acids, carboxylic acids, and alcohols efficiently [48]. RID was chosen because it is an attractive and universal type of detector that can be coupled with HPLC. The resulting HPLC-RID system represents a promising, efficient, sensitive, and reliable analytical technique to quantify alcohol, carbohydrates, and carboxylic acids [48]. The RID offers numerous advantages, including stability, robustness, and versatility [49]. In this case, using a UV-detector only would not have been feasible because it cannot detect ethanol or some of its oxidation products. Product detection could be improved by employing a dual detector system in series ((UVVIS) + RID) to obtain maximum information about the 11 possible products and substrate consumption. The first published investigation into an ethanol BFC employing HPLC results confirmed the electrochemical data and revealed that acetic acid (four electrons) was the only by-product [21].

When it comes to proposing a BFC device, the main challenge is the collection of all electrons from the fuel and its complete oxidation to obtain maximum energy during BFC operation. Although excellent results have been published, an analysis of the electrochemical results does not suffice to confirm complete fuel oxidation. Therefore, HPLC can be an essential tool to detect the $\mathrm{CO}_{2}$ formed in solution to confirm complete organic substrate oxidation. Detecting $\mathrm{CO}_{2}$ by an analytical technique is vital in the field of EBFCs because it demonstrates without doubt that the fuel has been completely oxidized. We have recently reported the detection of $\mathrm{CO}_{2}$ generation by HPLC [32]. To this end, we added $0.1 \mathrm{~mol} \mathrm{~L}^{-1}$ $\mathrm{NaOH}$ to the electrochemical cell after electrolysis, so that the RID detector could easily detect the resulting sodium carbonate as a negative chromatographic peak [32].

We also employed chromatographic results to confirm $\mathrm{CO}_{2}$ formation after long-term ethanol electrolysis at a hybrid electrode combining an organic catalyst, TEMPO, and the OxOx enzyme [33]. The products formed after electrolysis for $12 \mathrm{~h}$ confirmed that the hybrid electrode system (MWCNT-COOH/TEMPO-LPEI/OxOx) catalyzed multiple ethanol electrooxidation steps (Figure 3). Figure 3A,B display the results we obtained for the MWCNT-COOH/LPEI/bovine serum albumin (BSA) electrode system at 0 and $12 \mathrm{~h}$, respectively. In the absence of TEMPO or an enzyme, no products emerged for the control electrodes. The results confirmed that MWCNT-COOH only acted to enhance the electron transfer and electrical contact between the active sites of the enzymes and the electron collector and that it was active in the oxidation pathway. The system containing only $\mathrm{OxOx}$ (MWCNT-COOH/LPEI/OxOx) in the presence of ethanol gave a similar result (Figure 3C). The enzymatic system afforded no product because this enzyme was not active for alcohol. Nevertheless, HPLC analysis showed that the OxOx enzyme cleaved the acetic acid C-C bond and yielded formic acid as a by-product (Figure 3D).

As expected [38,50,51], ethanol oxidation at the TEMPO-LPEI electrocatalyst (MWCNT$\mathrm{COOH} / \mathrm{TEMPO}-\mathrm{LPEI} / \mathrm{BSA}$ ) produced acetic acid only. We have reported that TEMPO catalyzes ethanol oxidation, harvesting four electrons $\left(4 \mathrm{e}^{-}\right)$from this fuel (Figure 3E) [33]. To increase the number of harvested electrons, a hybrid system must be prepared by intro- 
ducing an enzyme that can cleave the $\mathrm{C}-\mathrm{C}$ bond (Figure 3F). Thus, the $\mathrm{CO}_{2}$ detected by HPLC (peak 4 in Figure 3) confirmed that ethanol C-C bond cleavage and collection of the 12 electrons were possible (Figure 3).

Analytical techniques such as nuclear magnetic resonance (NMR) and gas chromatography (GC) coupled with a thermal conductivity detector (TCD) have been proposed to detect electrolysis intermediates and products during the study of the catabolic steps of fuel oxidation $[34,36,37]$.

Even though the HPLC-RID technique provides good quantitative results, the difficulty in detecting volatile compounds such as acetaldehyde during the first catabolic step of ethanol oxidation has been the main reason for seeking new analytical techniques. Another issue is the need for obtaining high-resolution peaks to avoid misdetection of the target analytes. In this context, NMR is a powerful analytical technique to determine structural properties and to quantify and identify various compounds without the drawbacks of decomposition, sample modification, oxidation during analysis, or even total matrix loss, for instance $[52,53]$. In addition, compared to other analytical detection methods, such as ultraviolet (UV), infrared (IR), and refraction index, NMR can discriminate between compounds of similar structures by means of ${ }^{1} \mathrm{H}$ NMR or ${ }^{13} \mathrm{C}$ NMR analyses [54]. Our group identified $\mathrm{CO}_{2}$ by NMR after complete glycerol oxidation [35,37] and after long-term ethanol electrolysis in an ethanol BFC system (amino-TEMPO/OxDc) [46].

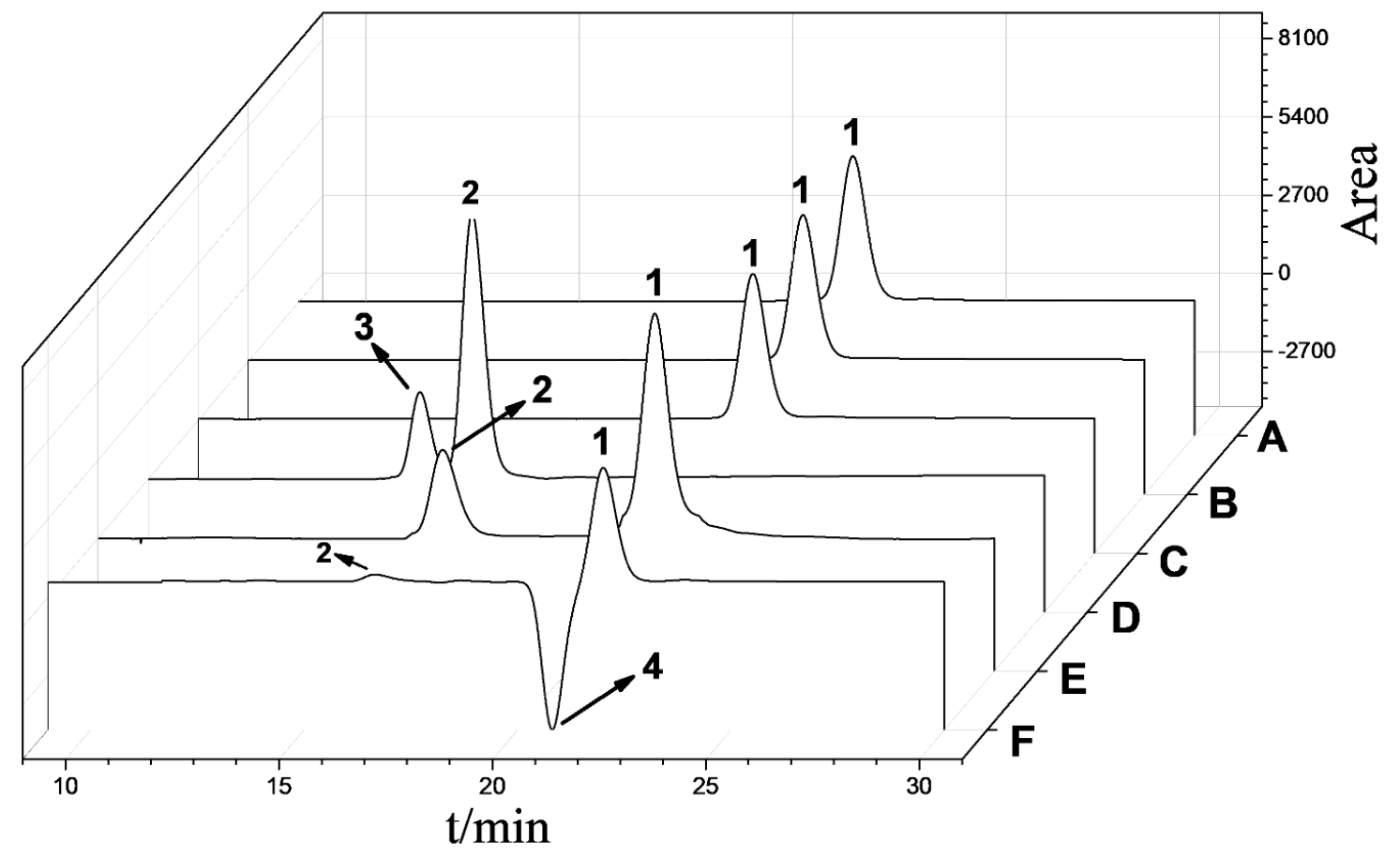

Figure 3. Chromatographic analysis during long-term ethanol electrolysis at different anode architectures: (A) MWCNT$\mathrm{COOH} /$ linear poly(ethylenimine) (LPEI)/BSA $(\mathrm{t}=0)$, $(\mathbf{B})$ MWCNT-COOH/LPEI/BSA $(\mathrm{t}=12 \mathrm{~h}),(\mathrm{C}) \mathrm{MWCNT}$ $\mathrm{COOH} / \mathrm{LPEI} /$ oxalate oxidase $(\mathrm{OxOx})(\mathrm{t}=12 \mathrm{~h}),(\mathrm{E}) \mathrm{MWCNT}-\mathrm{COOH} / \mathrm{TEMPO}-\mathrm{LPEI} / \mathrm{BSA}(\mathrm{t}=12 \mathrm{~h})$, and $(\mathrm{F}) \mathrm{MWCNT}$ $\mathrm{COOH} / \mathrm{TEMPO}-\mathrm{LPEI} / \mathrm{OxOx}(\mathrm{t}=12 \mathrm{~h})$ and during $30 \mathrm{mM}$ acetic acid electrolysis at (D) MWCNT-COOH/LPEI/OxOx ( $\mathrm{t}=12 \mathrm{~h}$ ). Peaks 1, 2, 3, and 4 correspond to ethanol, acetic acid, formic acid, and carbon dioxide, respectively. Reprinted with permission from [33]. Copyright 2020.

GC-TCD can efficiently detect $\mathrm{CO}_{2}$ formed in the headspace of an EBFC, providing more accurate results regarding how much fuel has been oxidized [36,55]. TCD is used to detect volatile compounds that show low response in other detectors, including UV detectors and RID. Compounds with good thermal conductivity, such as ammonia, hydrazine, and $\mathrm{CO}_{2}$, are the most suitable for this analytical technique and may also be applied for quantification $[56,57]$. Headspace GC-TCD has been demonstrated to detect $\mathrm{CO}_{2}$ efficiently 
during complete glycerol oxidation [34,36,55]. Our research group has applied GC-TCD to identify $\mathrm{CO}_{2}$ in a BFC containing a hybrid system based on MWCNT-COOH/pyreneTEMPO/OxDc, which confirmed that this bi-catalytic system collected 12 electrons from ethanol by completely oxidizing it to $\mathrm{CO}_{2}$ [34].

Apart from detecting $\mathrm{CO}_{2}$ and confirming complete fuel oxidation in either solution or the headspace, HPLC [32,33], NMR [46], and GC-TCD [34] are essential to understand how the catalyst bioelectrode interacts or reacts. These analytical techniques allow for the concentration of the by-products formed during fuel oxidation to be calculated and for the mass balance and faradaic efficiency to be determined. This is vital when it comes to understanding the mechanism and the contribution of the individual catalysts to the whole system. Straightforward use of analytical techniques for long-term electrochemical applications will be routinely required in any EBFC laboratory.

\section{Applications of Ethanol EBFCs for Biosensing}

\subsection{Enzymatic Biosensors}

Compared to chemical catalysts, enzymes have a high level of specificity and selectivity for the substrate. For this reason, modifying a bare surface with enzymes has become one of the most active areas of electroanalysis [58]. The relatively low stability of enzymes for use as biosensors can be easily overcome by choosing the appropriate conditions of $\mathrm{pH}$ and temperature and by immobilizing the enzyme properly [59]. Covering all of the literature concerning biosensors is out of the scope of this review, but several reviews have detailed the use of one or more enzymes as a biological component of the biosensor. Numerous studies have reported the application of ethanol biosensors [60-63]. In these investigations, two main enzymes, namely alcohol oxidase (AOx) [60,61] and ADH [62,63], have been successfully employed to determine alcohols. Chui et al. developed an amperometric ethanol biosensor by immobilizing ADH on the surface of a poly(vinyl alcohol)-multiwalled carbon nanotube (PVA-MWCNT) composite. The ethanol biosensor showed high sensitivity (196 nA mM ${ }^{-1}$ ) and fast response (about eight seconds) to detect ethanol, which enabled its use in real samples such as beer, red wine, and brandy [62]. A screen-printed carbon electrode modified with 5\% cobalt phthalocyanine (CoPC-SPCE) and containing AOx was applied as an ethanol amperometric biosensor [60]. The amperometric technique showed good performance and provided high precision and reliability for ethanol detection in beer [60]. For ethanol detection, a search of the Web of Science database using the keywords sensors, enzyme, and ethanol retrieved more than 10,886 entries from the Web of Science core collection. Figure $4 \mathrm{~A}$ depicts the timeline of these publications and shows that interest in this field has increased markedly since the 1990s. Figure 4B shows that the subject was mainly investigated in Japan, the USA, China, and Germany.

\subsubsection{Electrochemical Biosensors}

Electrochemical biosensors are characterized by their simplicity, sensitivity, reliability, and fast response. These biosensors provide exceptionally low detection limits and operate in a wide concentration range. Due to all these advantages, electrochemical biosensors constitute most of the developed biosensors [64].

In recent years, research into EBFCs has focused on developing enhanced hybrid architectures that can completely oxidize the fuel and can collect the maximum energy/electrons per fuel molecule. Obtaining EBFCs with high energy efficiency will allow these promising systems to be applied in the production of EBFC biosensors through energy management $[30,65,66]$. 


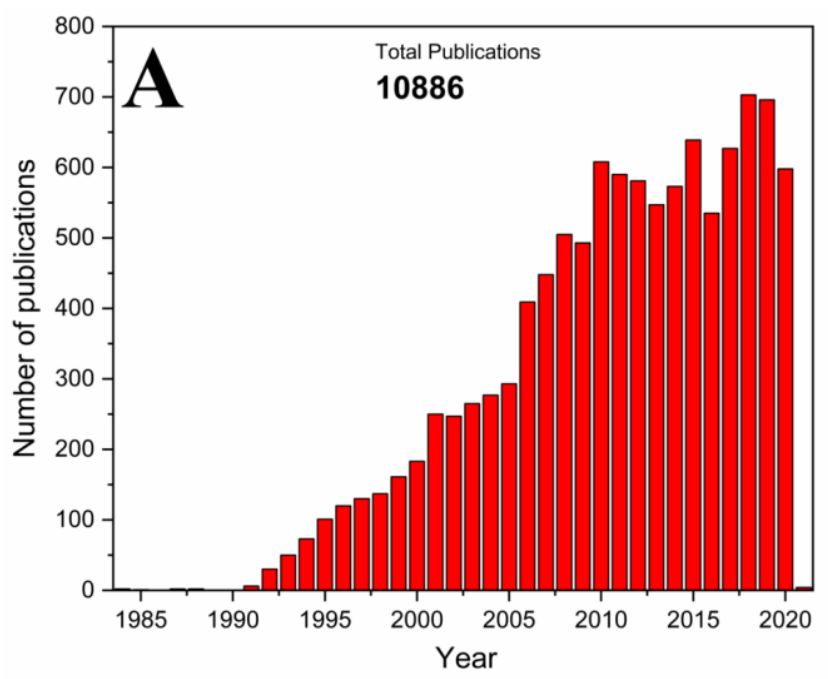

(a)

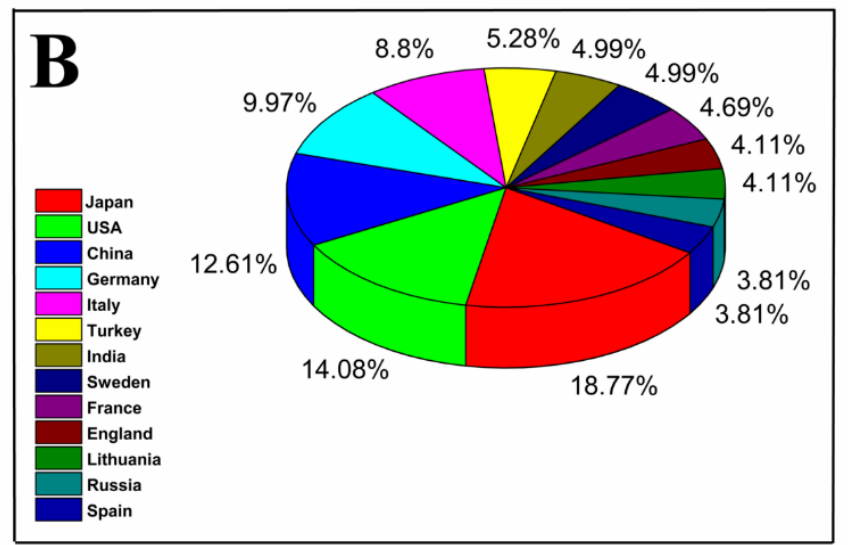

(b)

Figure 4. (A) Evaluation based on a literature search of the Web of Science database for publications regarding ethanol biofuel cells over the past 40 years and (B) publications about ethanol biosensors per country: search conducted in November/2020 at webofknowledge.com.

\subsubsection{Ethanol Self-Powered Biosensors (ESPBs)}

On the basis of some literature reviews, ethanol self-powered biosensors (ESPBs) have increasingly attracted researchers' interest due to their practical applications related to health, food analysis, and environmental monitoring [67-69]. Most reviews on biosensors have reported that these systems show high sensitivity and selectivity and provide fast response [31,68,69]. However, some issues must be overcome. In some cases, the low stability of these systems with respect to specific targets was reported as a recurring problem $[66,68]$. Therefore, new fuel cell designs that include structured materials and promising organic/biological catalysts must be employed to improve the stability of enzymatic self-powered biosensors [67,69]. The first self-powered enzymatic biosensor was based on the consumption of glucose; it involved an oxidoreductase enzyme at the anode and cytochrome c oxidase at the cathode (to reduce oxygen) [58]. Devices to detect other substrates such as glucose [58,70], lactate [58,71], cholesterol [72,73], and drugs and antibiotics [74] were recently developed. As stated previously, to a lesser extent, ethanol was used as an analyte for application in biosensors [68,75-77]. Schuhmann et al. [31] reported on a self-powered biosensor device based on ethanol $/ \mathrm{O}_{2}$ biofuel cells consisting of a bioanode modified with a $\beta$-nicotinamide adenine dinucleotide (NAD ${ }^{+}$)-ADH/redox polymer and a biocathode modified with AOx and horseradish peroxidase (HRP) to detect ethanol in a liquor. To improve the bioanode performance, the authors used a phenothiazine dye-modified redox polymer to recycle and reduce the $\mathrm{NAD}^{+}$cofactor overpotential. The chronoamperometric experiments revealed a linear current response for ethanol concentrations ranging from 0.1 to $1.0 \mathrm{mM}$. The proposed ethanol biofuel cell exhibited a high open-circuit voltage (OCV) of approximately $660 \mathrm{mV}$, arousing interest in the development of new ethanol self-powered energy conversion technology [31].

Gao et al. proposed another self-powered ethanol biosensor [78]. To construct the bioelectrode, the authors used liquid-crystalline lipidic cubic phases (LCPs) composed of monoolein $(\mathrm{MO})$ as a hosting matrix to co-entrap $\mathrm{ADH}$ and the electrocatalyst toluidine blue (TB). The ethanol biosensor had a detection limit of $0.09 \mathrm{mM}$ and linear ethanol concentration range up to $15.6 \mathrm{mM}$. The authors employed the system to detect ethanol in human serum with good reproducibility. An investigation into the performance of the ethanol/air EBFC by power density tests provided an OCV and maximum power density of $0.53 \mathrm{~V}$ and $12.0 \mu \mathrm{Wcm}^{-2}$, respectively [78]. 
Our group employed the hybrid bi-catalytic architecture consisting of MWCNT$\mathrm{COOH} /$ pyrene-TEMPO/OxDc [34] to develop a self-powered ethanol biosensor. Figure 5 illustrates the calibration curve of this hybrid system at various ethanol concentrations derived from chronoamperometric experiments.

The sensor response to a large ethanol concentration range $(0-2500 \mathrm{mM})$ showed that the current density $(j)$ increased after successive additions of different ethanol concentrations. After $2000 \mathrm{mM}$ ethanol, the system became saturated and $j_{\max }$ remained constant. From 0 to $100 \mathrm{mM}$ ethanol, the biosensor presented good linearity with a linear relationship $\left(R^{2}=0.9906\right)$ between the ethanol concentration and the current. The ethanol detection limit was $0.10 \mathrm{mM}$. These values were comparable to data achieved with other applied methods for self-powered ethanol biosensors [31,78].

The bioelectrode ability to generate high current densities in a wide range of ethanol concentrations allowed us to obtain a self-powered ethanol biosensor [30,31,75,79]. Figure 6 shows the power curves of the MWCNT-COOH/pyrene-TEMPO/OxDc,ethanol//Pt/C, $\mathrm{O}_{2}$ biofuel cell at different ethanol concentrations. The power density (Figure 6A) and the maximum current density, $\mathrm{I}_{\max }$ (Figure 6B) increased linearly with the ethanol concentration from 0 to $100 \mathrm{mM}$ ethanol. In the presence of $5 \mathrm{mM}$ ethanol, the power density and current density of the self-powered sensor reached values as high as $80 \mu \mathrm{W} \mathrm{cm}{ }^{-2}$ and $310 \mu \mathrm{A} \mathrm{cm}^{-2}$, respectively. The results showed that the current density and power density were a function of ethanol concentration, which clearly demonstrated that the BFC acted as a self-powered biosensor.

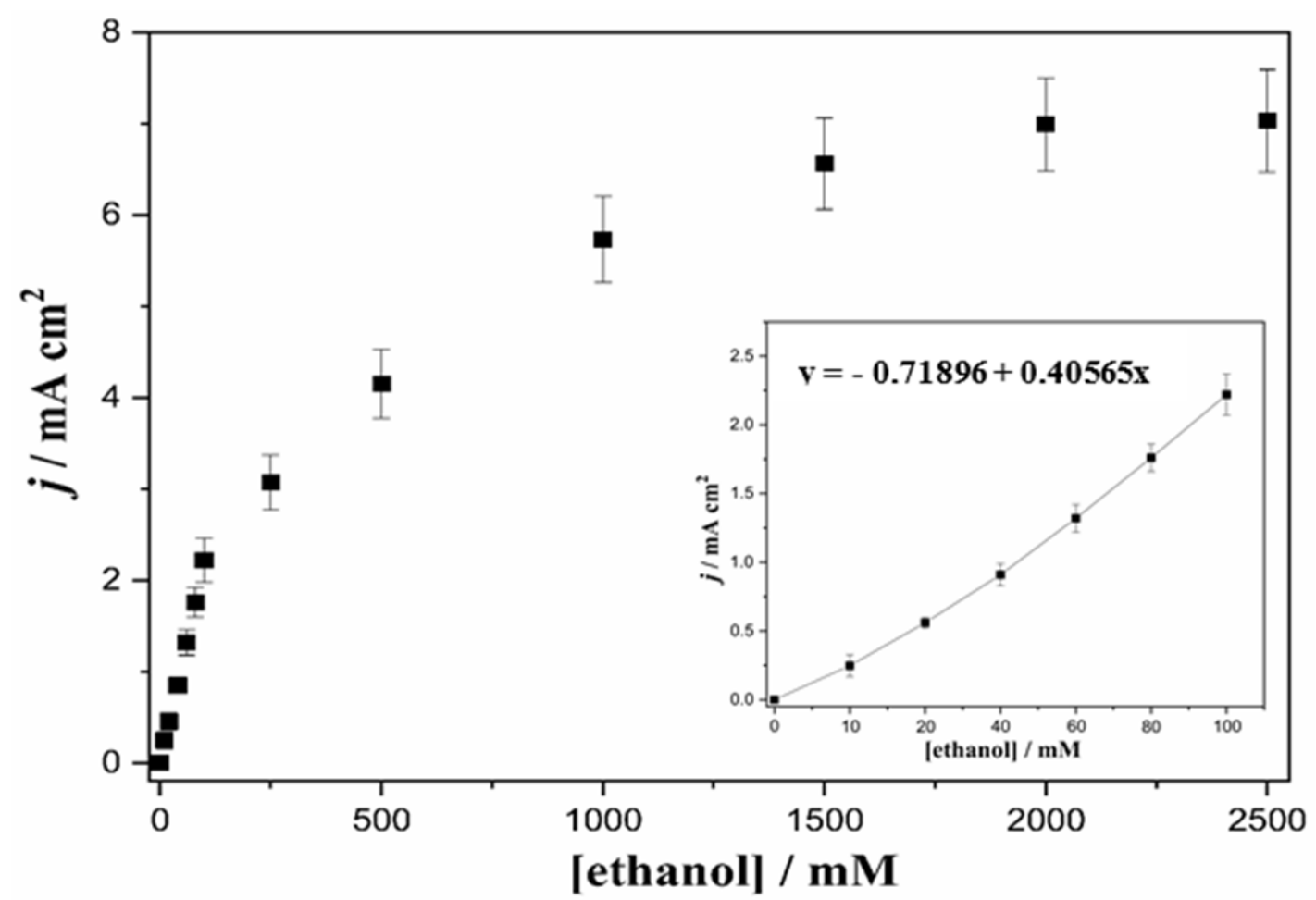

Figure 5. Calibration curve for increasing ethanol concentrations for the MWCNT-COOH/pyrene-TEMPO/OxDc electrode in $150 \mathrm{mM}$ citric acid-phosphate buffer at $\mathrm{pH}=5.2$ and $25^{\circ} \mathrm{C}$ : the error bars represent one standard deviation from the mean, $n=3$.

Table 1 summarizes the power curve results obtained for different ethanol biofuel cells. The results indicate that the designed MWCNT-COOH/pyrene-TEMPO/OxDc system achieved higher power density values compared to other systems evaluated for ethanol biofuel cells (BFCs). It is noteworthy that the hybrid catalytic architecture can be potentially employed in small bio-powered devices, which opens up opportunities for various biosensing applications. 

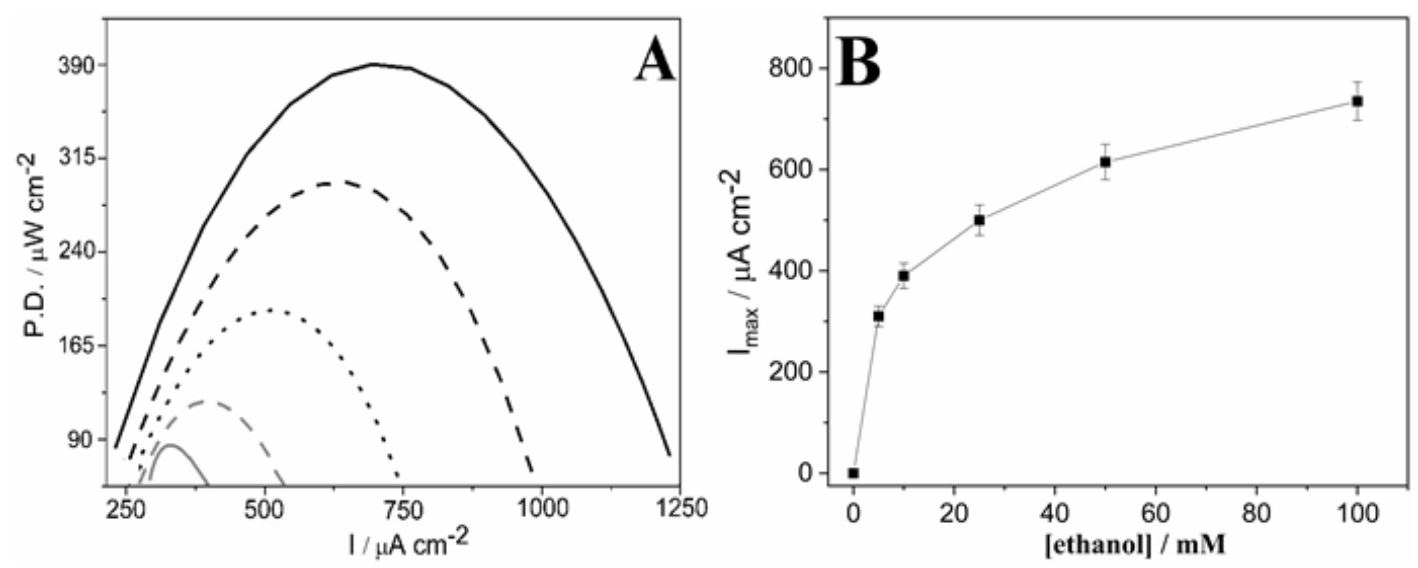

Figure 6. Representative power curves of the enzymatic biofuel cell (EBFC) as a function of ethanol concentration (0-100 mM) (A) and a scheme of the $150 \mathrm{mM}$ citric acid-phosphate buffer at $\mathrm{pH}=5.2$ and $25^{\circ} \mathrm{C}(\mathbf{B})$ : the error bars represent one standard deviation from the mean $(n=3)$.

Table 1. Power density generated for different ethanol self-powered biosensors (ESPB) ethanol biofuel cell architectures.

\begin{tabular}{|c|c|c|c|c|}
\hline Bioeletrode & $\begin{array}{c}\text { Fuel } \\
\text { Conc/mM }\end{array}$ & OCP (V) & $\begin{array}{c}\text { Power } \\
\text { Density }\left(\mu \mathrm{W} / \mathrm{cm}^{2}\right)\end{array}$ & Literature \\
\hline $\begin{array}{l}\text { MWCNT-COOH/Pyrene- } \\
\text { TEMPO/OxDc }\end{array}$ & $\mathrm{EtOH}$ & 0.598 & 388.0 & $\begin{array}{l}\text { Franco et al. Biosens. Bioelectron. } 154 \\
\text { (2020) } 112077\end{array}$ \\
\hline$M G+N a f i o n+A D H / A l d D H / N A D^{+}$ & $\mathrm{EtOH}$ & 0.510 & 340.0 & $\begin{array}{l}\text { Topcagic and Minteer, Electrochim. Acta } \\
51 \text { (2006) 2168-2172 }\end{array}$ \\
\hline $\begin{array}{l}\text { MWCNT-COOH/TEMPO- } \\
\text { LPEI/OxOx }\end{array}$ & $\mathrm{EtOH}$ & 0.492 & 302.5 & $\begin{array}{l}\text { Franco et al. Bioelectrochemistry } 130 \\
\text { (2019) } 107331\end{array}$ \\
\hline$A D H / \mathrm{TiO}_{2} \mathrm{NTs}-\mathrm{TCPP}$ & $\mathrm{EtOH}$ & 1.13 & 270.0 & $\begin{array}{l}\text { Zhang et al. Nano Energy } 11 \text { (2015) } \\
48-55\end{array}$ \\
\hline $\begin{array}{c}\text { poly- }(M G-P Y R)+M W C N T s+\text { Nafion } \\
+ \text { ADH/AldDH/NAD } \\
\end{array}$ & $\mathrm{EtOH}$ & 0.503 & 275.2 & $\begin{array}{l}\text { Bonfin et al. J. Electroanal. Chem. } 844 \\
\text { (2019) 43-48 }\end{array}$ \\
\hline $\begin{array}{c}M G+M W C N T s+\text { Nafion }+ \\
\text { ADH/AldDH/NAD }\end{array}$ & $\mathrm{EtOH}$ & 0.540 & 186.0 & $\begin{array}{l}\text { Franco et al. J. Electrochem. Soc } 165 \\
\text { (2018) H575-H579 }\end{array}$ \\
\hline $\begin{array}{c}M G+M W C N T S+P A M A M+ \\
A D H / N A D^{+}\end{array}$ & $\mathrm{EtOH}$ & 0.356 & 189.0 & $\begin{array}{l}\text { Fenga et al. Electrochim. Acta } 106 \text { (2013) } \\
\text { 109-113 }\end{array}$ \\
\hline$M G+A D H / N A D^{+}$ & $\mathrm{EtOH}$ & 0.340 & 53.0 & Moore et al. Lab Chip 5 (2005) 218-225 \\
\hline $\begin{array}{c}\text { MWCNTs + PAMAM + } \\
P Q Q-A D H / P Q Q-A l d D H\end{array}$ & $\mathrm{EtOH}$ & $\begin{array}{c}\text { Not } \\
\text { reported }\end{array}$ & 38.4 & $\begin{array}{l}\text { Neto et al. Electrochim. Acta } 87 \text { (2013) } \\
\text { 323-329 }\end{array}$ \\
\hline $\begin{array}{c}M G+M W C N T s+L P E I+ \\
A D H / A l d D H / N A D^{+}\end{array}$ & $\mathrm{EtOH}$ & 0.530 & 35.5 & $\begin{array}{l}\text { Lau et al. Int. J. Hydrog. Energy } 40 \\
\text { (2015) 14661-14666 }\end{array}$ \\
\hline $\begin{array}{c}\text { MG + MWCNTs + Nafion + } \\
\text { ADH/NAD }\end{array}$ & $\mathrm{EtOH}$ & 0.149 & 32.0 & $\begin{array}{l}\text { Fenga et al. Electrochim. Acta } 106 \text { (2013) } \\
\text { 109-113 }\end{array}$ \\
\hline ADH + Saccharomyces cerevisiae & $\mathrm{EtOH}$ & 0.350 & 7.07 & $\begin{array}{l}\text { Pagnoncelli et al. Bioelectrochemistry } 122 \\
\text { (2018) 11-25 }\end{array}$ \\
\hline$Q H-A D H$ & $\mathrm{EtOH}$ & 0.130 & 1.50 & $\begin{array}{l}\text { Ramanavicius et al. Biosens. Bioelectron. } \\
24 \text { (2008) 761-766 }\end{array}$ \\
\hline
\end{tabular}

$\mathrm{MG}=$ Methylene Green. $\mathrm{TiO}_{2} \mathrm{NTs}=$ Hydrothermally prepared $\mathrm{TiO}_{2}$ nanotube. TCPP $=$ Meso-tetrakis(4-carboxyphenyl)porphyrin. Poly- $($ MG-PYR $)=$ Poly (methylene green-pyrrole). PPQ = Pyrroloquinoline Quinone. $\mathrm{LPEI}=$ Linear poly (ethylenimine). QH $=\mathrm{Quino}-$ hemoprotein.

\subsection{Approaches to Improve the ESPB Technology: Supercapacitor/Biofuel Cell Hybrid Device}

Many research groups have been encouraged to make BFCs a more accessible technology; these cells are directly associated with the development of ESPB devices, which 
provide ways to obtain clean and renewable energy and have potential use as an alternative energy source for low power electronic devices [65,80,81].

Despite recent advances, employing BFCs in electronic devices is no easy task: BFCs have limitations, such as insufficient stability, power, and energy production to promote autonomous energy sources. Although an increasing number of publications have reported satisfactory power densities, the values obtained to date are far from practical use in long-term applications.

A possible solution to develop efficient ESPBs is to develop devices that can generate/store energy when they are coupled with supercapacitors (SC) [82]. SCs are highpower electrochemical energy storage systems with high capacitance electrodes that can be charged and discharged by fast and reversible processes, thereby allowing an almost unlimited number of charge/discharge cycles $[83,84]$. SCs can function as a battery (high energy storage capacity) while providing capacitor performance (fast charge and power supply) [85,86].

Therefore, in SC-EBFCs, the electrode internal capacitance is used to accumulate the electrical charge generated at the biobattery (organic catalyst and enzyme) [87]. Some examples of hybrid biodevices that integrate supercapacitors such as biobatteries and biosensors and use enzymatic systems have been developed recently [88-90]. Pankratov et al. [91] developed a glucose self-charged biocapacitor based on graphite foil modified with a polyaniline/carbon nanotubes (CNT's) composite as the capacitor; the EBFC consisted of nanobiostructures based on three-dimensional gold nanoparticles (AuNPs) at the anode and a AuNPs biocathode. The authors achieved a maximum power density of $1.2 \mathrm{~mW} \mathrm{~cm}{ }^{-2}$ at $0.38 \mathrm{~V}$. This conjugated system proved an efficient glucose self-charging device that generated 170 times higher power density compared to the EBFC alone [91].

The supercapacitive properties of CNTs used to store charges in SC-EBFCs have been widely reported [80,92]. Agnes et al. [80] reported on a hybrid SC-EBFC based on a matrix of compressed CNT pellets as SC combined with GOx at the anode. The system displayed high-pulsed power discharges. In addition, the generated energy was stored within the CNT matrix, which enhanced the stability of the system. The hybrid system produced 40,000 pulses for five days, providing $2 \mathrm{~mW}$ per pulse of discharge [80].

Considering the excellent results obtained with the hybrid systems and the advantages of employing ethanol, building a hybrid SC-EBFC system would be interesting because it would allow environmentally sustainable SC-EBFCs to be developed for applications that require different power/current density ranges and durations of operation, enabling portable devices, such as biosensors, to be produced [65,81,82,93].

Attempts to employ the hybrid system MWCNT-COOH/pyrene-TEMPO/OxDc to prepare a self-powered biosensor device to detect ethanol will be reported in the future. However, Figure 7 shows the proposed representative model for a MWCNTCOOH/pyreneTEMPO/OxDc,ethanol//Pt $/ \mathrm{C}, \mathrm{O}_{2}$ device for electric power generation based on ethanol oxidation. The energy generated in the EBFC (a) is charged into the capacitor via a charge pump-integrated circuit (b) until the capacitor (c) reaches maximum capacity. Thus, the rate at which the capacitor is charged may be directly proportional to the efficiency of the bioelectrocatalytic ethanol oxidation reaction. When the capacitor voltage reaches a set value, the stored electrical energy can be discharged from the capacitor to activate a device such as an LED bulb. 


\section{Charge pump integrated circuit (b)}

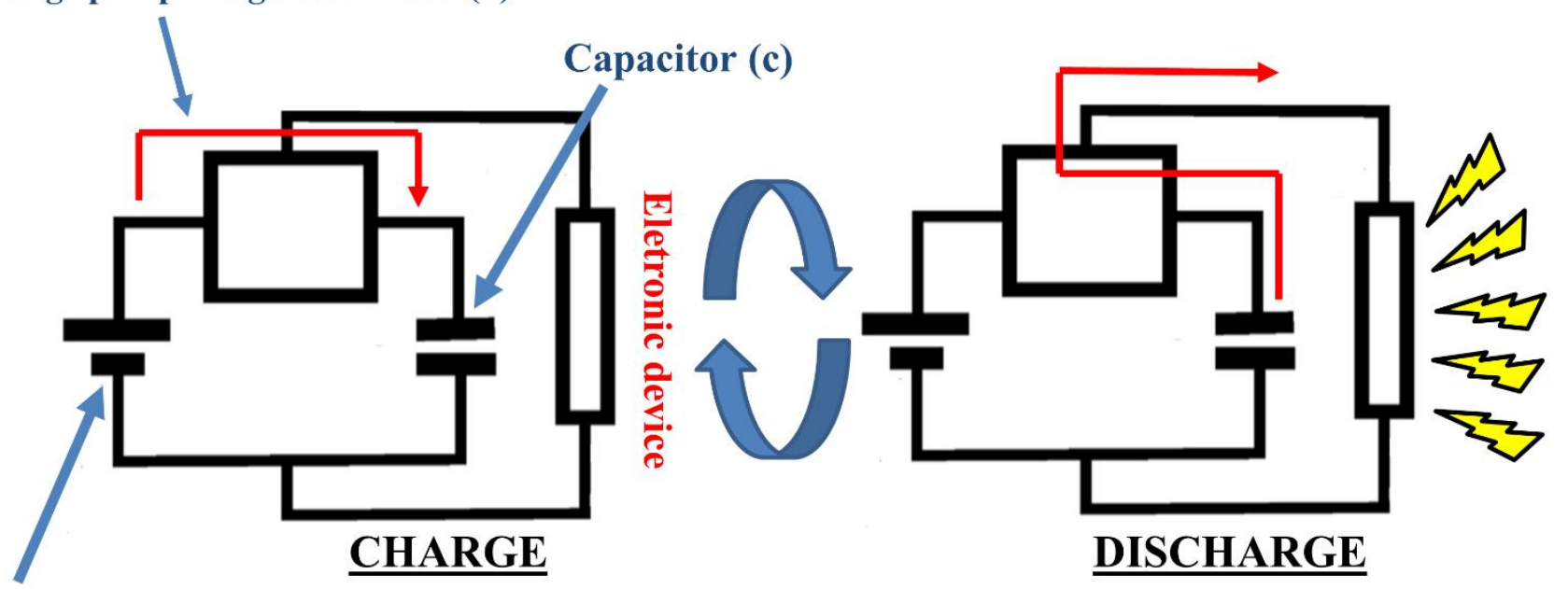

$\operatorname{EBFC~(a)~}$

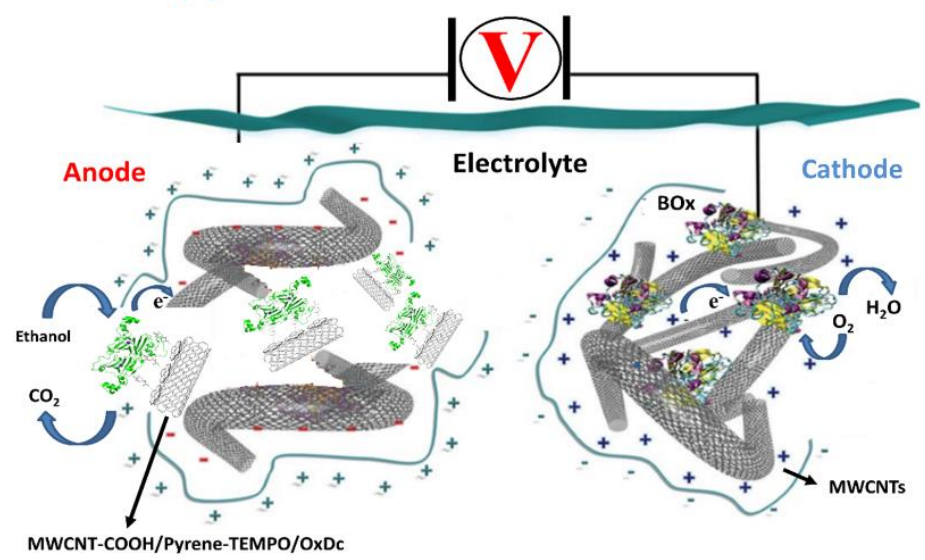

Figure 7. Representative model of the principle of a supercapacitor (SC)-EBFC: a charge pump-integrated circuit (b) is employed to scale up the voltage of the $\operatorname{EBFC}(\mathbf{a})$, and a capacitor $(\mathbf{c})$ is used to store the electrical energy. When the capacitor voltage reaches the set value, the stored electrical energy can be discharged from the capacitor to activate a device, such as an LED bulb. At the anode is OxDC (oxalate decarboxylase enzyme), and at the cathode is BOx (bilirubin oxidase).

\section{Conclusions}

Enzymatic biofuel cells have advanced in terms of catalytic activity and energy production rate, but several approaches have been proposed to overcome the problems related to EBFC performance and stability. Remarkably, hybrid bi-catalytic bioelectrodes containing an organic catalyst (pyrene-TEMPO), a decarboxylase enzyme (OxDc), and modified carbon nanotubes have been able to increase the bioelectrode surface area, thereby enhancing the energetic performance of the hybrid system and improving the EBFC lifetime.

We have shown that the biobattery composed of MWCNT-COOH/pyrene-TEMPO/ $\mathrm{OxDc}$,ethanol $/ / \mathrm{Pt} / \mathrm{C}, \mathrm{O}_{2}$ has potential use in small bio-powered devices with linear response ranges toward ethanol $(0.1 \mathrm{mM})$. This is an improvement that brings EBFCs closer to biosensing applications in the real world. A further improvement could be the use of hybrid SC-EBFC systems to overcome the issues of EBFCs. Such hybrid systems could be an alternative to achieving high-performance hybrid EBFC-based self-powered biosensors without the need for an external electrical power supply. This could allow for the development of ethanol EBFC biosensors that may be valuable for the determination of ethanol in real samples.

Future research on ethanol EBFCs for biosensing should focus on engineering approaches capable of improving the capacitance of the hybrid system and therefore in- 
creasing the energy storage and efficiency of the EBFC, which will enhance the analytical performance of the biosensor.

Author Contributions: Conceptualization, methodology, software, validation, formal analysis and investigation: (J.H.F.); resources: (A.R.D.A.) and (S.D.M.); data curation: (J.H.F.), (A.R.D.A.) and (S.D.M.); writing—original draft preparation: (J.H.F.); writing—review and editing: (J.H.F.), (A.R.D.A.) and (S.D.M.); visualization: (A.R.D.A.) and (S.D.M.); supervision: (A.R.D.A.) and (S.D.M.); project administration: (A.R.D.A.) and (S.D.M.); funding acquisition: (A.R.D.A.) and (S.D.M.). All authors have read and agreed to the published version of the manuscript.

Funding: The authors are grateful for the financial support from Brazilian research funding agencies FAPESP (2017/20431-7) and (2018/24180-1). Coordenação de Aperfeiçoamento de Pessoal de Nível Superior Brasil (CAPES) Finance Code 001, as well as the Army Research Office MURI (W911NF-14$1-0263)$.

Conflicts of Interest: The authors declare no conflict of interest.

\section{References}

1. Potter, M.C. Electrical effects accompanying the decomposition of organic compounds. Proc. R. Soc. Lond. Ser. B Biol. Sci. 1911, 84, 260-276. [CrossRef]

2. Yahiro, A.; Lee, S.; Kimble, D. Bioelectrochemistry. Biochim. Biophys. Acta BBA Spéc. Sect. Biophys. Subj. 1964, 88, 375-383. [CrossRef]

3. Minteer, S.D.; Liaw, B.Y.; Cooney, M.J. Enzyme-based biofuel cells. Curr. Opin. Biotechnol. 2007, 18, 228-234. [CrossRef]

4. Durand, F.; Kjaergaard, C.H.; Suraniti, E.; Gounel, S.; Hadt, R.G.; Solomon, E.I.; Mano, N. Bilirubin oxidase from Bacillus pumilus: A promising enzyme for the elaboration of efficient cathodes in biofuel cells. Biosens. Bioelectron. 2012, 35, 140-146. [CrossRef]

5. Willner, I.; Yan, Y.-M.; Tel-Vered, R.; Willner, B. Integrated Enzyme-Based Biofuel Cells-A Review. Fuel Cells 2009, 9, 7-24. [CrossRef]

6. Higgins, S.R.; Lau, C.; Atanassov, P.; Minteer, S.D.; Cooney, M.J. Hybrid Biofuel Cell: Microbial Fuel Cell with an Enzymatic Air-Breathing Cathode. ACS Catal. 2011, 1, 994-997. [CrossRef]

7. Neto, S.A.; De Andrade, A.R. New Energy Sources: The Enzymatic Biofuel Cell. J. Braz. Chem. Soc. 2013, 24, 1891-1912. [CrossRef]

8. Moehlenbrock, M.J.; Minteer, S.D. Extended lifetime biofuel cells. Chem. Soc. Rev. 2008, 37, 1188-1196. [CrossRef] [PubMed]

9. Barton, S.C.; Gallaway, J.; Atanassov, P. Enzymatic Biofuel Cells for Implantable and Microscale Devices. Chem. Rev. 2004, 104, 4867-4886. [CrossRef] [PubMed]

10. Bullen, R.; Arnot, T.; Lakeman, J.; Walsh, F.C. Biofuel cells and their development. Biosens. Bioelectron. 2006, 21, 2015-2045. [CrossRef]

11. Falk, M.; Villarrubia, C.W.N.; Babanova, S.; Atanassov, P.; Shleev, S. Biofuel Cells for Biomedical Applications: Colonizing the Animal Kingdom. ChemPhysChem 2013, 14, 2045-2058. [CrossRef]

12. Sokic-Lazic, D.; Minteer, S.D. Citric acid cycle biomimic on a carbon electrode. Biosens. Bioelectron. 2008, 24, 939-944. [CrossRef] [PubMed]

13. Zebda, A.; Alcaraz, J.-P.; Vadgama, P.; Shleev, S.; Minteer, S.D.; Boucher, F.; Cinquin, P.; Martin, D.K. Challenges for successful implantation of biofuel cells. Bioelectrochemistry 2018, 124, 57-72. [CrossRef] [PubMed]

14. Gamella, M.; Koushanpour, A.; Katz, E. Biofuel cells Activation of micro and macro Electronic devices. Bioelectrochemistry 2018, 119, 33-42. [CrossRef] [PubMed]

15. Gellett, W.; Kesmez, M.; Schumacher, J.; Akers, N.; Minteer, S.D. Biofuel Cells for Portable Power. Electroanal. Int. J. Dev. Fundam. Pract. Asp. Electroanal. 2010, 22, 727-731. [CrossRef]

16. Yu, E.H.; Scott, K. Enzymatic Biofuel Cells-Fabrication of Enzyme Electrodes. Energies 2010, 3, 23-42. [CrossRef]

17. Tam, T.K.; Pita, M.; Ornatska, M.; Katz, E. Biofuel cell controlled by enzyme logic network-Approaching physiologically regulated devices. Bioelectrochemistry 2009, 76, 4-9. [CrossRef]

18. González-Guerrero, M.J.; Esquivel, J.P.; Molas, D.S.; Godignon, P.; Del Campo, F.J.; Giroud, F.; Minteer, S.D.; Sabaté, N. Membraneless glucose $/ \mathrm{O}_{2}$ microfluidic enzymatic biofuel cell using pyrolyzed photoresist film electrodes. Lab Chip 2013, 13, 2972. [CrossRef]

19. Sokic-Lazic, D.; De Andrade, A.R.; Minteer, S.D. Utilization of enzyme cascades for complete oxidation of lactate in an enzymatic biofuel cell. Electrochim. Acta 2011, 56, 10772-10775. [CrossRef]

20. Zhu, Z.; Sun, F.; Zhang, X.; Zhang, Y.-H.P. Deep oxidation of glucose in enzymatic fuel cells through a synthetic enzymatic pathway containing a cascade of two thermostable dehydrogenases. Biosens. Bioelectron. 2012, 36, 110-115. [CrossRef]

21. Franco, J.H.; Minteer, S.D.; De Andrade, A.R. Product Analysis of Operating an Ethanol/ $\mathrm{O}_{2}$ Biofuel Cell Shows the Synergy between Enzymes within an Enzymatic Cascade. J. Electrochem. Soc. 2018, 165, H575-H579. [CrossRef]

22. Neto, S.A.; Minteer, S.D.; De Andrade, A.R. Developing ethanol bioanodes using a hydrophobically modified linear polyethylenimine hydrogel for immobilizing an enzyme cascade. J. Electroanal. Chem. 2018, 812, 153-158. [CrossRef] 
23. Rasmussen, M.; Abdellaoui, S.; Minteer, S.D. Enzymatic biofuel cells: 30 years of critical advancements. Biosens. Bioelectron. 2016, 76, 91-102. [CrossRef] [PubMed]

24. Pereira, A.; Gonçalves, A.; Pagnoncelli, K.; Crespilho, F.N.; De Souza, J.C.P. Bioelectrooxidation of Ethanol Using NAD-Dependent Alcohol Dehydrogenase on Oxidized Flexible Carbon Fiber Arrays. J. Braz. Chem. Soc. 2017, 28, 1698-1707. [CrossRef]

25. Pagnoncelli, K.C.; Pereira, A.R.; Sedenho, G.C.; Bertaglia, T.; Crespilho, F.N. Ethanol generation, oxidation and energy production in a cooperative bioelectrochemical system. Bioelectrochemistry 2018, 122, 11-25. [CrossRef] [PubMed]

26. Neto, S.A.; Almeida, T.D.S.; Palma, L.; Minteer, S.D.; De Andrade, A.R. Hybrid nanocatalysts containing enzymes and metallic nanoparticles for ethanol/O2 biofuel cell. J. Power Sour. 2014, 259, 25-32. [CrossRef]

27. Ribeiro, J.; Dos Anjos, D.M.; Leger, J.-M.; Hahn, F.; Olivi, P.; De Andrade, A.R.; Tremiliosi-Filho, G.; Kokoh, K.B. Effect of W on $\mathrm{PtSn} / \mathrm{C}$ catalysts for ethanol electrooxidation. J. Appl. Electrochem. 2008, 38, 653-662. [CrossRef]

28. Purgato, F.L.S.; Olivi, P.; Leger, J.-M.; De Andrade, A.R.; Tremiliosi-Filho, G.; Gonzalez, E.R.; Lamy, C.; Kokoh, K.B. Activity of platinum-tin catalysts prepared by the Pechini-Adams method for the electrooxidation of ethanol. J. Electroanal. Chem. 2009, 628, 81-89. [CrossRef]

29. Ivanov, I.; Vidaković, T.; Sundmacher, K. Recent Advances in Enzymatic Fuel Cells: Experiments and Modeling. Energies 2010, 3, 803-846. [CrossRef]

30. Lia, X.; Lia, D.; Zhanga, Y.; Lvd, P.; Fengc, Q.; Weiab, Q. Encapsulation of enzyme by metal-organic framework for singleenzymatic biofuel cell-based self-powered biosensor. Nano Energy 2020, 68, 104308. [CrossRef]

31. Ruff, A.; Pinyou, P.; Nolten, M.; Conzuelo, F.; Schuhmann, W. A Self-Powered Ethanol Biosensor. ChemElectroChem 2017, 4, 890-897. [CrossRef]

32. Franco, J.H.; Neto, S.A.; Hickey, D.P.; Minteer, S.D.; De Andrade, A.R. Hybrid catalyst cascade architecture enhancement for complete ethanol electrochemical oxidation. Biosens. Bioelectron. 2018, 121, 281-286. [CrossRef]

33. Franco, J.H.; De Almeida, P.Z.; Abdellaoui, S.; Hickey, D.P.; Ciancaglini, P.; Polizeli, M.D.L.T.M.; Minteer, S.D.; De Andrade, A.R. Bioinspired architecture of a hybrid bifunctional enzymatic/organic electrocatalyst for complete ethanol oxidation. Bioelectrochemistry 2019, 130, 107331. [CrossRef]

34. Franco, J.H.; Klunder, K.J.; Lee, J.; Russell, V.; De Andrade, A.R.; Minteer, S.D. Enhanced electrochemical oxidation of ethanol using a hybrid catalyst cascade architecture containing pyrene-TEMPO, oxalate decarboxylase and carboxylated multi-walled carbon nanotube. Biosens. Bioelectron. 2020, 154, 112077. [CrossRef] [PubMed]

35. Abdellaoui, S.; Hickey, D.P.; Stephens, A.R.; Minteer, S.D. Recombinant oxalate decarboxylase: Enhancement of a hybrid catalytic cascade for the complete electro-oxidation of glycerol. Chem. Commun. 2015, 51, 14330-14333. [CrossRef] [PubMed]

36. Macazo, F.C.; Hickey, D.P.; Abdellaoui, S.; Sigman, M.S.; Minteer, S.D. Polymer-immobilized, hybrid multi-catalyst architecture for enhanced electrochemical oxidation of glycerol. Chem. Commun. 2017, 53, 10310-10313. [CrossRef] [PubMed]

37. Hickey, D.P.; McCammant, M.S.; Giroud, F.; Sigman, M.S.; Minteer, S.D. Hybrid Enzymatic and Organic Electrocatalytic Cascade for the Complete Oxidation of Glycerol. J. Am. Chem. Soc. 2014, 136, 15917-15920. [CrossRef]

38. Lauber, M.B.; Stahl, S.S. Efficient Aerobic Oxidation of Secondary Alcohols at Ambient Temperature with an ABNO/NOx Catalyst System. ACS Catal. 2013, 3, 2612-2616. [CrossRef]

39. Campbell, A.S.; Jeong, Y.J.; Geier, S.M.; Koepsel, R.R.; Russell, A.J.; Islam, M.F. Membrane/Mediator-Free Rechargeable Enzymatic Biofuel Cell Utilizing Graphene/Single-Wall Carbon Nanotube Cogel Electrodes. ACS Appl. Mat. Interfaces 2015, 7, 4056-4065. [CrossRef]

40. Vincent, K.A.; Li, X.; Blanford, C.F.; Belsey, N.A.; Weiner, J.H.; Armstrong, F.A. Enzymatic catalysis on conducting graphite particles. Nat. Chem. Biol. 2007, 3, 761-762. [CrossRef]

41. Merkoçi, A.; Pumera, M.; Llopis, X.; Pérez, B.; Del Valle, M.; Alegret, S. New materials for electrochemical sensing VI: Carbon nanotubes. TrAC Trends Anal. Chem. 2005, 24, 826-838. [CrossRef]

42. Ogawa, Y.; Yoshino, S.; Miyake, T.; Nishizawa, M. Surfactant-assisted direct electron transfer between multi-copper oxidases and carbon nanotube-based porous electrodes. Phys. Chem. Chem. Phys. 2014, 16, 13059-13062. [CrossRef]

43. Katz, E.; Willner, I. Biomolecule-Functionalized Carbon Nanotubes: Applications in Nanobioelectronics. ChemPhysChem 2004, 5, 1084-1104. [CrossRef]

44. Li, Y.; Chen, S.-M.; Sarawathi, R. Membraneless Enzymatic Biofuel Cells Based on Multi-Walled Carbon Nanotubes. Int. J. Electrochem. Sci. 2011, 6, 3776-3788.

45. Neto, S.A.; Forti, J.; Zucolotto, V.; Ciancaglini, P.; De Andrade, A.; De Andrade, A.R. Development of nanostructured bioanodes containing dendrimers and dehydrogenases enzymes for application in ethanol biofuel cells. Biosens. Bioelectron. 2011, 26, 2922-2926. [CrossRef]

46. Franco, J.H.; Klunder, K.J.; Russell, V.; De Andrade, A.R.; Minteer, S.D. Hybrid enzymatic and organic catalyst cascade for enhanced complete oxidation of ethanol in an electrochemical micro-reactor device. Electrochim. Acta 2020, 331, 135254. [CrossRef]

47. Sokic-Lazic, D.; Arechederra, R.L.; Treu, B.L.; Minteer, S.D. Oxidation of Biofuels: Fuel Diversity and Effectiveness of Fuel Oxidation through Multiple Enzyme Cascades. Electroanal. Int. J. Dev. Fundam. Pract. Asp. Electroanal. 2010, 22, 757-764. [CrossRef]

48. Llano, T.; Quijorna, N.; Andrés, A.; Coz, A. Sugar, acid and furfural quantification in a sulphite pulp mill: Feedstock, product and hydrolysate analysis by HPLC/RID. Biotechnol. Rep. 2017, 15, 75-83. [CrossRef] [PubMed] 
49. Wade, J.H.; Bailey, R.C. Refractive Index-Based Detection of Gradient Elution Liquid Chromatography using Chip-Integrated Microring Resonator Arrays. Anal. Chem. 2014, 86, 913-919. [CrossRef]

50. Pozzi, G.; Cavazzini, M.; Quici, S.; Benaglia, M.; Dell'Anna, G. Poly (ethylene glycol)-Supported TEMPO: An Efficient, Recoverable Metal-Free Catalyst for the Selective Oxidation of Alcohols. Org. Lett. 2004, 6, 441-443. [CrossRef]

51. Zwolinski, K.M.; Chmielewski, M.J. TEMPO-Appended Metal-Organic Frameworks as Highly Active, Selective, and Reusable Catalysts for Mild Aerobic Oxidation of Alcohols. ACS Appl. Mat. Interfaces 2017, 9, 33956-33967. [CrossRef] [PubMed]

52. Ward, R.L. A Complete Introduction to Modern NMR Spectroscopy (Macomber, Rodger S.). J. Chem. Educ. 1999, 76, 473. [CrossRef]

53. Weljie, A.M.; Newton, J.; Jirik, F.R.; Vogel, H.J. Evaluating Low-Intensity Unknown Signals in Quantitative Proton NMR Mixture Analysis. Anal. Chem. 2008, 80, 8956-8965. [CrossRef] [PubMed]

54. Valverde, J.; This, H.; Vignolle, M. Quantitative Determination of Photosynthetic Pigments in Green Beans Using Thin-Layer Chromatography and a Flatbed Scanner as Densitometer. J. Chem. Educ. 2007, 84, 1505. [CrossRef]

55. Abdellaoui, S.; Chavez, M.S.; Matanovic, I.; Stephens, A.R.; Atanassov, P.; Minteer, S.D. Hybrid molecular/enzymatic catalytic cascade for complete electro-oxidation of glycerol using a promiscuous NAD-dependent formate dehydrogenase from Candida boidinii. Chem. Commun. 2017, 53, 5368-5371. [CrossRef]

56. Kay, J.; Thomas, R.; Gruenhagen, J.; Venkatramani, C. Simultaneous quantitation of water and residual solvents in pharmaceuticals by rapid headspace gas chromatography with thermal conductivity detection (GC-TCD). J. Pharm. Biomed. Anal. 2021, 194, 113796. [CrossRef]

57. O'Keefe, W.; Ng, F.; Rempel, G. Validation of a gas chromatography/thermal conductivity detection method for the determination of the water content of oxygenated solvents. J. Chromatogr. A 2008, 1182, 113-118. [CrossRef] [PubMed]

58. Katz, E.; Bückmann, A.F.; Willner, I. Self-Powered Enzyme-Based Biosensors. J. Am. Chem. Soc. 2001, 123, 10752-10753. [CrossRef]

59. Karube, I.; Nomura, Y. Enzyme sensors for environmental analysis. J. Mol. Catal. B Enzym. 2000, 10, 177-181. [CrossRef]

60. Boujtita, M. Development of a disposable ethanol biosensor based on a chemically modified screen-printed electrode coated with alcohol oxidase for the analysis of beer. Biosens. Bioelectron. 2000, 15, 257-263. [CrossRef]

61. Wen, G.; Zhang, Y.; Shuang, S.; Dong, C.; Choi, M.M. Application of a biosensor for monitoring of ethanol. Biosens. Bioelectron. 2007, 23, 121-129. [CrossRef]

62. Tsai, Y.-C.; Huang, J.-D.; Chiu, C.-C. Amperometric ethanol biosensor based on poly (vinyl alcohol)-Multiwalled carbon nanotube-Alcohol dehydrogenase biocomposite. Biosens. Bioelectron. 2007, 22, 3051-3056. [CrossRef]

63. Li, L.; Lu, H.; Deng, L. A sensitive NADH and ethanol biosensor based on graphene-Au nanorods nanocomposites. Talanta 2013, 113, 1-6. [CrossRef] [PubMed]

64. Thévenot, D.R.; Toth, K.; Durst, R.A.; Wilson, G.S. Electrochemical biosensors: Recommended definitions and classification. Biosens. Bioelectron. 2001, 16, 121-131. [CrossRef]

65. Xiao, X.; Xia, H.-Q.; Wu, R.; Bai, L.; Yan, L.; Magner, E.; Cosnier, S.; Lojou, E.; Zhu, Z.; Liu, A. Tackling the Challenges of Enzymatic (Bio)Fuel Cells. Chem. Rev. 2019, 119, 9509-9558. [CrossRef] [PubMed]

66. Gu, C.; Kong, X.; Liu, X.; Gai, P.; Li, F. Enzymatic Biofuel-Cell-Based Self-Powered Biosensor Integrated with DNA Amplification Strategy for Ultrasensitive Detection of Single-Nucleotide Polymorphism. Anal. Chem. 2019, 91, 8697-8704. [CrossRef]

67. Conzuelo, F.; Ruff, A.; Schuhmann, W. Self-Powered bioelectrochemical devices. Curr. Opin. Electrochem. 2018, 12, 156-163. [CrossRef]

68. Fu, L.; Liu, J.; Hu, Z.; Zhou, M. Recent Advances in the Construction of Biofuel Cells Based Self-powered Electrochemical Biosensors: A Review. Electroanalysis 2018, 30, 2535-2550. [CrossRef]

69. Grattieri, M.; Minteer, S.D. Self-Powered Biosensors. ACS Sens. 2018, 3, 44-53. [CrossRef]

70. Pinyou, P.; Conzuelo, F.; Sliozberg, K.; Vivekananthan, J.; Contin, A.; Poller, S.; Plumeré, N.; Schuhmann, W. Coupling of an enzymatic biofuel cell to an electrochemical cell for self-powered glucose sensing with optical readout. Bioelectrochemistry 2015, 106, 22-27. [CrossRef]

71. Hickey, D.P.; Reid, R.C.; Milton, R.D.; Minteer, S.D. A Self-Powered amperometric lactate biosensor based on lactate oxidase immobilized in Dimethylferrocene-Modified LPEI. Biosens. Bioelectron. 2016, 77, 26-31. [CrossRef] [PubMed]

72. Han, Y.; Chabu, J.M.; Hu, S.; Deng, L.; Liu, Y.-N.; Guo, S. Rational Tuning of the Electrocatalytic Nanobiointerface for a "Turn-Off" Biofuel-Cell-Based Self-Powered Biosensor for p53 Protein. Chem. A Eur. J. 2015, 21, 13045-13051. [CrossRef]

73. Wang, Y.; Ge, L.; Wang, P.; Yan, M.; Yu, J.; Ge, S. A Three-Dimensional origami based Immune-Biofuel cell for Self-Powered, Low-Cost, and sensitive point of care testing. Chem. Commun. 2014, 50, 1947-1949. [CrossRef] [PubMed]

74. Conzuelo, F.; Vivekananthan, J.; Poller, S.; Pingarrón, J.M.; Schuhmann, W. Immunologically Controlled Biofuel Cell as a Self-Powered Biosensor for Antibiotic Residue Determination. ChemElectroChem 2014, 1, 1854-1858. [CrossRef]

75. Lansdorp, B.; Ramsay, W.; Hamidand, R.; Strenk, E. Wearable Enzymatic Alcohol Biosensor. Sensors 2019, 19, 2380. [CrossRef] [PubMed]

76. Campbell, A.S.; Kim, J.; Wang, J. Wearable electrochemical alcohol biosensors. Curr. Opin. Electrochem. 2018, 10, 126-135. [CrossRef]

77. Hooda, V.; Gahlaut, A.; Hooda, V. A novel amperometric biosensor for rapid detection of ethanol utilizing gold nanoparticles and enzyme coupled PVC reaction cell. Environ. Technol. 2020, 1-11. [CrossRef] 
78. Wu, G.; Yao, Z.; Fei, B.; Gao, F. An Enzymatic Ethanol Biosensor and Ethanol/Air Biofuel Cell Using Liquid-Crystalline Cubic Phases as Hosting Matrices to Co-Entrap Enzymes and Mediators. J. Electrochem. Soc. 2017, 164, G82-G86. [CrossRef]

79. Bollella, P.; Gorton, L.; Antiochia, R. Direct Electron Transfer of Dehydrogenases for Development of 3rd Generation Biosensors and Enzymatic Fuel Cells. Sensors 2018, 18, 1319. [CrossRef]

80. Agnès, C.; Holzinger, M.; Le Goff, A.; Reuillard, B.; Elouarzaki, K.; Tingry, S.; Cosnier, S. Supercapacitor/biofuel cell hybrids based on wired enzymes on carbon nanotube matrices: Autonomous reloading after high power pulses in neutral buffered glucose solutions. Energy Environ. Sci. 2014, 7, 1884-1888. [CrossRef]

81. Falk, M.; Shleev, S. Hybrid Dual-Functioning electrodes for combined ambient energy harvesting and charge storage: Towards Self-Powered systems. Biosens. Bioelectron. 2019, 126, 275-291. [CrossRef]

82. Sode, K.; Yamazaki, T.; Lee, I.; Hanashi, T.; Tsugawa, W. BioCapacitor: A novel principle for biosensors. Biosens. Bioelectron. 2016, 76, 20-28. [CrossRef]

83. Béguin, F.; Presser, V.; Balducci, A.; Frackowiak, E. Carbons and Electrolytes for Advanced Supercapacitors. Adv. Mat. 2014, 26, 2219-2251. [CrossRef] [PubMed]

84. Poonam; Sharma, K.; Arora, A.; Tripathi, S. Review of supercapacitors: Materials and devices. J. Energy Storage 2019, 21, 801-825. [CrossRef]

85. Winter, M.; Brodd, R.J. What Are Batteries, Fuel Cells, and Supercapacitors? Chem. Rev. 2004, 104, 4245-4270. [CrossRef]

86. Skunik-Nuckowska, M.; Grzejszczyk, K.; Stolarczyk, K.; Bilewicz, R.; Kulesza, P.J. Integration of supercapacitors with enzymatic biobatteries toward more effective Pulse-Powered use in Small-Scale energy harvesting devices. J. Appl. Electrochem. 2014, 44, 497-507. [CrossRef]

87. Deeke, A.; Sleutels, T.H.J.A.; Hamelers, H.V.M.; Buisman, C.J.N. Capacitive Bioanodes Enable Renewable Energy Storage in Microbial Fuel Cells. Environ. Sci. Technol. 2012, 46, 3554-3560. [CrossRef] [PubMed]

88. Shen, F.; Pankratov, D.; Pankratova, G.; Toscano, M.D.; Zhang, J.; Ulstrup, J.; Chi, Q.; Gorton, L. Supercapacitor/biofuel cell hybrid device employing biomolecules for energy conversion and charge storage. Bioelectrochemistry 2019, 128, 94-99. [CrossRef]

89. Alsaoub, S.; Conzuelo, F.; Gounel, S.; Mano, N.; Schuhmann, W.; Ruff, A. Introducing Pseudocapacitive Bioelectrodes into a Biofuel Cell/Biosupercapacitor Hybrid Device for Optimized Open Circuit Voltage. ChemElectroChem 2019, 6, $2080-2087$. [CrossRef]

90. Shleev, S.; González-Arribas, E.; Falk, M. Biosupercapacitors. Curr. Opin. Electrochem. 2017, 5, 226-233. [CrossRef]

91. Pankratov, D.; Blum, Z.; Suyatin, D.B.; Popov, V.O.; Shleev, S. Self-Charging Electrochemical Biocapacitor. ChemElectroChem 2013, 1, 343-346. [CrossRef]

92. Knoche, K.L.; Hickey, D.P.; Milton, R.D.; Curchoe, C.L.; Minteer, S.D. Hybrid Glucose/ $\mathrm{O}_{2}$ Biobattery and Supercapacitor Utilizing a Pseudocapacitive Dimethylferrocene Redox Polymer at the Bioanode. ACS Energy Lett. 2016, 1, 380-385. [CrossRef]

93. Pankratov, D.; Blum, Z.; Shleev, S. Hybrid Electric Power Biodevices. ChemElectroChem 2014, 1, 1798-1807. [CrossRef] 